\title{
POESÍA HISPANOAMERICANA FIN DE SIGLO: EDUARDO ESPINA Y EL BARROCOCÓ
}

\author{
POR \\ Miguel-ÁNGel ZAPATA \\ University of Colorado
}

La poesía de Eduardo Espina (Montevideo, Uruguay), sorprende en primera instancia por los cambios radicales que aporta en cuanto a la forma del poema y a la actualización de la sintaxis. ${ }^{1}$ Su escritura asimila tanto el lenguaje poético del Siglo de Oro español como las experiencias prevanguardistas de algunos de sus coterráneos. No en vano, esta lírica continúa una tradición de ruptura iniciada en el Uruguay a principios de siglo. Así pues, la poética de Espina se comunica en varios sentidos con las obras de Julio Herrera y Reissig (1875-1910) y Delmira Agustini (1886-1914), quienes nacieron en Montevideoal igual que el Conde Lautréamont y Jules Laforgue, aunque estos dos últimos poetas dejaron el Uruguay cuando eran adolescentes y murieron muy jóvenes en Francia. ${ }^{2}$ A comienzos de este siglo Herrera y Reissig introducía una serie de cambios en la elaboración artística del poema, y sus contribuciones en este campo se inician antes de la publicación de Trilce (1922) de César Vallejo y Altazor (1931) de Vicente Huidobro. La poesía de Herrera y Reissig encuentra su identidad en el deseo y la fantasía erótica: el poema establece un diálogo intenso de ensueños y fantasías encontrando una coherencia en el curso de una sintaxis aparentemente dislocada e ilógica. Su obra es un canto al frenesí y una de sus vetas principales se concentra en las sensaciones que devienen del placer corpóreo y del lenguaje. Poemas como "La torre de las esfinges", terminado un año antes de su muerte (1910), "La vida" y "Desolación absurda" escritos entre 1900 y 1903, son prueba del nuevo diseño poético que fundaba este poeta uruguayo.

\footnotetext{
${ }^{1}$ Eduardo Espina ha publicado: Valores personales (Buenos Aires: Ediciones La Máquina de Escribir, 1983) y La caza nupcial (Buenos Aires: Ediciones Último Reino, 1993).

${ }^{2}$ En el caso de la poesía de Julio Herrera y Reissig véase el libro de Gwen Kirkpatrick The Dissonant Legacy of Modernismo. Lugones, Herrera y Reissig, and the Voices of Modern Spanish American Poetry (Berkeley: University of California Press, 1990). Consúltese el capitulo; "The Frenzy of Modernismo: Herrera y Reissig", 170-197. También el libro de Eduardo Espina, El disfraz de modernidad (México: Universidad Autónoma del Estado de México, 1992). Para Delmira Agustini ver entre otros: Manuel Alvar, La poesía de Delmira Agustini (Sevilla: Escuela de Estudios Hispanoamericanos, 1958; Clara Silva, Pasión y gloria de Delmira Agustini; su vida y obra (Buenos Aires: Losada, 1972) y Jorge Medina Vidal, et al., Delmira Agustini: seis ensayos críticos (Montevideo: Ciencias, 1982).
} 
De la misma manera la poesía de Delmira Agustini es importante e innovadora dentro de la lírica uruguaya y también una de las figuras que más ha influido en el devenir de la nueva poesía hispanoamericana. Delmira Agustini explora intensamente los placeres carnales, y sus deseos y desilusiones son plasmados en un lenguaje oscuro (especialmente en sus últimos poemas de El rosario de Eros y Los astros del abismo (1924) donde se concentran también otros temas como el paso del tiempo y los recuerdos. La esencia de la poesía de esta autora uruguaya es una pasión desbordante que interpreta la supremacia de la mujer en su relación con el amado: "Ella" es la que remonta vuelo, la que abandona, alterando en su discurso la visión tradicional de la mujer en las relaciones amorosas. Su poesía es una exaltación interminable que la hace decir " $i Q u i e r o$ más vida para amar!" dejando constancia de que su vida es el impulso hacia el deseo y los placeres constantes. Estos placeres y deseos son descritos con un lenguaje desposeído de las ataduras de la censura religiosa y de cualquier tabú.

No cabe duda que las voces de Julio Herrera y Reissig y Delmira Agustini han dejado una zona lingüistica abierta que los nuevos poetas uruguayos e hispanoamericanos han explorado con denuedo; una zona demarcada por las pasiones y el deseo, por el cuerpo y su satisfacción plena. La poesía de Julio Herrera continúa enriqueciendo a voces más jóvenes en el contexto hispanoamericano de hoy. Gwen Kirkpatrick, viendo la influencia de la obra de Herrera en autores posteriores a su tiempo ha escrito que "Herrera y Reissig's example affected several major writers of the twentieth century (notably César Vallejo) with his foreshortened focus and syntactical experiments." (Kirkpatrick 172-173). Este tipo de poesía ha sido asimilado no solamente por Vallejo en sus experimentos sintácticos, sino también por algunos poetas uruguayos que han sabido recoger algunas constantes de la poesía de Herrera, especialmente en el campo de la experimentación con el lenguaje. Por otro lado se ubica la influencia de Delmira Agustini con su lenguaje apasionado y oscuro, plasmado en imágenes eróticas que reflejan una intensa vida interior y una manera muy particular del percibir el mundo con sus deseos más extremos. Dos voces que exaltan la pasión erótica y que reconstruyen la sintaxis del lenguaje para crear una comunicación más abierta con el lector.

Luego de las rupturas de Herrera y Reissig y Delmira Agustini, los poetas del Uruguay han continuado enriqueciéndose y buscando otras direcciones lingüísticas en el poema. Algunos nombres de importancia destacan en ese ámbito de asimilación y renovación en la poesía uruguaya contemporánea: Idea Vilariño, Amanda Berenguer, Ida Vitale, Marosa di Giorgio, Enrique Fierro, Roberto Echavarren, Eduardo Milán y Eduardo Espina, principalmente. En Eduardo Espina se percibe el diálogo continuador y la irreverencia frente al lenguaje en un ambiente posmoderno a fines del siglo veinte. Espina, al igual que Herrera y Reissig, desarrolla imágenes que describen su experiencia erótica y su relación con el lenguaje, encontrando ritmos sensuales que van reproduciendo las sensaciones amorosas de los cuerpos y su euforia sin límites. Estas sensaciones y deseos eróticos comienzan a aparecer con ciertos lujos y detalles en Valores personales (1983), libro en el que se inicia el proceso de experimentación, construcción y reconstrucción del lenguaje, sobre todo en la alteración de la sintaxis. Valores personales es un homenaje al lenguaje y a poetas que el autor admira: Lautréamont, Sade, Emily Dickinson, Góngora, entre otros, y también la figura de Marilyn Monroe. Los poemas que rinden homenaje a la belleza de 
Marilyn Monroe y a la violencia sexual de Sade anticipaban la veta que Espina desarrollaría con mayor profundidad en La caza nupcial. En Valores personales se construye la poética rectora del autor. El lenguaje se convierte en el centro por donde fluye una cadena de imágenes que sorprenden por su dificultad. Acerca de este libro Eduardo Milán escribió:

La especificidad de este poeta está dada por el especial manejo de la sintaxis. En este sentido su experiencia se asimila a la de la última generación latinoamericana - la de los sesenta en adelante - cuyo leitmotiv es la recuperación de la sintaxis como práctica rectora. Pero en el caso de Espina no se trata de una sintaxis lógica, de frases organizadas según el esquema del sujeto-verbo-predicado. Se trata de una sintaxis que se da por acoplamiento de grupos fónicos ordenados según la respiración, cuya fractura delimita el campo de las distintas imágenes. Su poesía es eso: un encadenamiento de imágenes divididas por el corte del aliento, como si el texto progresara por una reflexión fraseológica que pautara y regulara su estructura. (Milán 55)

Desde Valores personales (1983) hasta La caza nupcial (1993) el acoplamiento de imágenes ha venido madurando y los resultados obtenidos son impresionantes. Luego de diez años de intensa labor creadora — de corrección y meditación del poema- Espina publica La caza nupcial donde se cuajan los valores personales del poeta, que son los productos del placer y del lenguaje. En este libro, de casi doscientas páginas, el deseo y la unión amorosa son piezas fundamentales para entender el sentido de los textos. El cuerpo y el lenguaje son algunas constantes principales de esta voz que matiza sus expresiones con colores intensos y tejidos lisos como la popelina: "Lenguaje en sarong de púrpura popelina $\mathrm{de} \mathrm{la/} \mathrm{bella} \mathrm{diciendo} \mathrm{bien} \mathrm{que} \mathrm{me} \mathrm{follas} \mathrm{escarabajo"} \mathrm{(29).} \mathrm{Algunos} \mathrm{colores} \mathrm{como} \mathrm{el} \mathrm{púrpura}$ habían sido contextualizados de diferente manera por Góngora en el Polifemo. En los versos de Espina la intensidad es diferente; el motor del deseo aquí es la voz de la amada que expresa su satisfacción plena.

Algunos poetas hispanoamericanos se han identificado con Góngora no solamente por el tratamiento que éste da a su lenguaje - con sus imágenes aéreas, cultismos y ornamentación - sino por representar una búsqueda incesante en la elaboración del poema. El poema se convierte en la casa que se destruye y reconstruye, un mobiliario que se renueva constantemente. En Hispanoamérica, José Lezama Lima se ubica como el continuador de los experimentos gongorinos pero agregando ingredientes del trópico caribeño. También en este sentido experimentador se encuentran los chilenos Enrique Lihn y Oscar Hahn, los peruanos Carlos Germán Belli y Rodolfo Hinostroza, el argentino Néstor Perlongher y el cubano Severo Sarduy, entre otros. Estos poetas nombrados junto con Eduardo Espina se sienten ligados a la poesía peninsular, estableciendo una relación estrecha a nivel del lenguaje y sus experimentaciones. ${ }^{3}$ En este sentido, la poesía de Espina, siguiendo a Góngora, Herrera y Reissig y Lezama Lima, reinventa un lenguaje que se inspira en la

\footnotetext{
${ }^{3}$ Christine Legault ha escrito: "Bien ha subrayado John Beverley que quizás por eso la literatura hispanoamericana siga tan marcada por la poética gongorina, con sus veleidades exploratorias y su anhelo de encontrar una cultura posiblemente más adecuada a sus necesidades auténticas. Porque si la llamada de Góngora fallo en ser oída y comprendida en su época, es tiempo que sea reformulada ahora en la escena del presente" (127). Tesis doctoral: "Poesia hispanoamericana postvanguardista y manierismo: dimensiones formales de una intertextualidad cultural", Universidad de Iowa, 1987.
} 
búsqueda de una nueva tipografía del poema y en la creación de una intensidad distinta que alimente su contexto.

Luego de una primera lectura, los poemas de La caza mupcial podrían ser considerados como textos barrocos. Partiendo de esta premisa sus versos se acercarían al canon gongorino, especialmente los de corte amoroso. Recordemos que en algunos poemas de Góngora las descripciones no se refieren estrictamente al acto carnal-amoroso, como es el caso de las descripciones del rostro de Galatea, donde resalta el cabello, la frente y las orejas. ${ }^{4}$ Donde se podría relacionar la lírica de Espina con la del poeta cordobés es en la invasión de los colores (púrpura, rosa, blanco) que identifican el paisaje (el lecho, el cuerpo) y en el empleo de los cultismos, sobre todo en algunas palabras aparentemente inencontrables en los diccionarios. Los signos barrocos de La caza nupcial se encuentran en la acumulación de palabras, visiones (conjunciones, adverbios, sueños) y ornamentos que se forman verticalmente como las columnas de una iglesia chirrigueresca. El lenguaje sirve de apoyatura a millares de sensaciones que fluyen en el texto y que son parte esencial de esta poética. El poeta escribe y describe el acto creador y amoroso para dar cuenta de la suma de su placer. Aquí lo barroco ejerce su poder en cuanto a la producción de placer: el placer de acoplar imágenes y sensaciones que no tienen fin. A propósito de este sentido del barroco, Severo Sarduy dice:

La exclamación infalible que suscita toda capilla de Churriguera o del Aleijadinho, toda estrofa de Góngora o de Lezama, todo acto barroco, ya pertenezca a la pintura o a la repostería — “ ;Cuánto trabajo! —, implica un apenas disimulado adjetivo: ¡Cuánto trabajo perdido, cuanto juego y desperdicio, cuánto esfuerzo sin funcionalidad! Es el superyó del homo faber, el ser-para-el-trabajo el que aquí se enuncia impugnando el regodeo, la voluptuosidad del oro, el fasto, la desmesura, el placer. (Sarduy 210)

Por otro lado, Eduardo Espina en una entrevista definía su poética como "barrococó":

Defino, o mejor dicho, comprendo mi poesía como "barrococó". Dos estrategias estéticas confluyen en el mismo lenguaje. La constante variación formal que hace del texto un espacio de desplazamientos, la desarticulación de la acción y de la unidad, la banalización de toda la realidad con un gesto deliberadamente anacrónico y la cursilería adaptada del habla diaria, que son elementos propios del rococo, dialogan con modalidades diseñantes propias del barroco, como son el horror al espacio vacío (que hace desbordar significantes en la página), el renunciamiento a nombrar una concretidad discernible, el apego por lo corporal, y el propósito de reivindicar la fealdad como suprema manifestación estética. (“Coloquios" 120-121)

Espina habla de la existencia de una desarticulación versal en el poema, debido a que en sus textos los desplazamientos de los verbos y los adjetivos funcionan por asociación no de

\footnotetext{
${ }^{4}$ Véase el estudio de Paul Julian Smith sobre la sexualidad en la literatura hispánica: The Body Hispanic. Gender and Sexuality in Spanish and Spanish American Literature (New York: Oxford University Press, 1989). Ver "The Polifemo: Narrative and Catachresis" (60). También contiene estudios sobre la sexualidad en Pablo Neruda, César Vallejo, Federico García Lorca, Carlos Fuentes, Manuel Puig, entre otros.
} 
sentido sino por afinidad con el ritmo..$^{5}$ La mayoría de los poemas de este libro se asemejan a un rectángulo (corto o largo) donde cada palabra tiene su espacio exacto, adquirido no gracias a los beneficios del ordenador sino al arduo trabajo de acoplar y reordenar en el vacío, versos endecasílabos y alejandrinos. Transcribo como ejemplo el poema "Razón de todas las cosas":

El deseo resuelto en hendidura.

De lo demás quedará la memoria un vaho de alcanfor en el baño una tinaja vacía como parte de una casa en otra época y dos o tres palabras que resuman todo: la membrana del espejo y acaso el humo después de las cenizas $y$ un barco hundido en el antro del jardín donde tierra baldía del tiempo empolve los anhelos. Samsara de neblí en la higuera donde ni ayer del pasado o hez del presente queda por atenuar cuando en verdad nada queda en la voz del lenguaje ni oblonga imagen de esperanto, clepsidras de agua moribunda, eros y eras del cuerpo que osaron la feliz unidad, cerviz, cáliz y altazor. Pero el futuro, paso de un río nuevo que corrre al revés, será a su azoro un cero cuando sale del somier la suma sorprendida y nada no más que en la cuenta la lápida de los mismos loando en los labios la luz alrededor. (185)

En este poema, cada sílaba se va acomodando a las otras que fluyen en el texto para formar una columna vertical. Las paredes del poema, como en las del soneto, controlan el río

\footnotetext{
${ }^{5}$ Cabe mencionar que el poeta argentino Néstor Perlongher (1948-1992) llamó -admirador de la poesía de Espina-neobarroso a su lenguaje, por un lado debido al color de barro del Río de la Plata, y por el otro, como una continuidad (enriquecida) del Barroco practicado por Góngora y Lezama Lima. Perlongher habla de un lenguaje neobarroco, barroso, que tiene como característica la "mezcla de jergas que pueden proceder de cualquier parte ... pasados por la soledad ambulante del exilio, interior o exterior ...." ("Coloquios" 286). Pero también Severo Sarduy ya había impuesto mucho antes el término neobarroco. Para este caso ver el capitulo de Enrico Mario Santí "Sobre Severo Sarduy: el efecto barroco" (153-157) en Escrituray tradición. Texto, crítica y poética en la literatura hispanoamericana (Barcelona: Editorial Laia, 1987). Aun cuando este capítulo no estudia las nuevas denominaciones de Perlongher y Espina sobre el Barroco, sirve como guía para el entendimiento de los efectos de estas nuevas propuestas.
} 
silábico de la sintaxis. La poética de Espina funciona mejor en este caso por "la desarticulación de la acción y de la unidad" la cual irrumpe desde los primeros versos cuando se propone al deseo como imagen vital de la hendidura. La memoria también aparece a manera de signo salvador contra el olvido aunque "nada queda en la voz del lenguaje ni oblonga/ imagen de esperanto". El hablante reflexiona sobre la experiencia final de su aventura y también sobre la posible inutilidad de la poesía. En este poema se puede apreciar el trabajo de orfebre del poeta. Aquí vemos que cada palabra existe para dar sentido a los ornamentos, para que hablen y tengan voz: "eros y eras/ del cuerpo que osaron la feliz/ unidad, cerviz, cáliz y altazor". Estos versos guardan una concordancia con respecto a la unidad buscada en la vida y en el amor. El cuerpo florece como centro porque el "erotismo es una manera de ver y de vivir en el mundo. Aún si se expresa a través del deseo más extremo o de la más tangible física del cuerpo, siempre es un más allá de sí mismo" (Sucre 345). El amor florece en el mundo de eros simbolizado por la cerviz (el cuello y las siete vértebras), el cáliz (la cubierta de la flor) y por altazor que emprende vuelo más allá de sí mismo.

Los deseos extremos de La caza nupcial son la celebración del goce carnal donde el lenguaje viaja por distintos contornos, dando detalles de los amores y sus sonidos en poemas largos y breves. En la mayoría de los poemas se resuelve la unión amorosa de dos seres que se atraen magnéticamente por el deseo, y en la que se concluye que el amor no lastima: "Salían del amor ilesos" ("Epígrafe" 60). En un poema breve, "Imágenes de la voz", se lee:

\author{
De espaldas en el espejo, nada \\ de venado veloz ni natación de \\ sílabas a solas en el lenguaje; \\ apenas un haz de luz y aquello \\ si lo era, como asombro de más \\ cielo y carne invisible de dos \\ en el aire canjeando soledades. (117)
}

El erotismo de Espina gira entre el goce corpóreo y la agilidad del lenguaje fusionados en la página en blanco (del cuerpo). La caza nupcial establece también un diálogo con el Arcipreste de Hita, pero esta conexión funciona en el sentido de que ambas obras describen sus aventuras amorosas, pero éstas se diferencian en las intensidades y en la desmesura de su erotismo. Espina escribe un libro de experiencias eróticas en las que el deseo y el acto sexual son la fuerza motriz de su existencia. Las voces somáticas que se escuchan en este libro son la fortaleza lingüística, el soporte mismo de la palabra poética. El hablante de Espina no cuenta sus experiencias para mostrar y prevenir "las maneras e maestrías e sotilezas engañosas del loco amor", como argumentaba el Arcipreste, sino que resume su poética en "el deseo resuelto en hendidura" (185). Es decir, que la abertura, la grieta (el sexo) es el centro rector por donde se desliza esta poética.

En otros poemas se relaciona y explica la unión permanente de deseo y lenguaje, e intimidad y lascivia forman un solo cuerpo textual. El poema " ¿Una pluma de salamandra o un labio de más?" (72-73) dice: “... donde a riesgo de todo y de/merodeo en el alfabeto escribo de lo íntimo/de la libídine rasgando una letra y lo digo/frente al espejo del lenguaje 
que no miente ... porque este embeleso de palabras me fascina/ y porque ellas a su manera, también te aman." La suma de la poética de Espina, de esta manera, se centraliza en la intimidad del lenguaje y en su sensualidad. Propone lo que Vicente Huidobro pedía en Temblor de cielo (1931): "Ante todo hay que saber cuántas veces debemos aban/donar nuestra novia y huir de sexo en sexo hasta el fin/ de la tierra" (141). La liberación de su lenguaje consiste en la liberación de la sexualidad humana, de la misma forma que Huidobro proponía en su poema de 1931, donde los ismos desaparecen para combinar, como en el caso de Espina, vida y sexualidad, gineceo y lascivia, memoria y tiempo. ${ }^{6}$

La caza nupcial asimila la tradición poética hispánica a través de intertextualidades que van adquiriendo un nuevo significado en el poema. Pedro Lastra, al respecto, habla de una de las características fundamentales de la nueva poesía hispanoamericana:

Un tercer aspecto ... es el recurso a la intertextualidad. Tal recurso es ahora un procedimiento singularizador, por la frecuencia y la variedad con que se manifiesta. Los textos como productividad, al decir de Julia Kristeva, como un espacio en el cual se dan cita, se desplazan, se acentúan, se condensan, se profundizan o aligeran otras textualidades. Estas textualidades de base suelen provenir, como se sabe, de lugares muy distintos ... (Catorce poetas hispanoamericanos de hoy $\mathrm{xv}$ )

En este sentido Espina realiza algunos "préstamos" que los acopla al contexto de su poesía. Así emplea el término "bolo alimenticio" que Carlos Germán Belli (Lima, 1927) utiliza en uno de sus libros En alabanza del bolo alimenticio (1979); pero en el caso de Espina adquiere una connotación erótica. ${ }^{7}$ En este caso sirve como modelo el poema "Tan segura como el horóscopo": "... antes del bello bolo alimenticio/ cuando la boca a juntarse con su/ origen viene ..."(24), y en el poema "Ay amor cuánto líquido me cuestas": "... como escapándole al fuego sazonadas/por un santo que al bolo alimenticio/ bendice con buches ..." (61). Y remontándose a épocas más distantes el español renueva sus viejas vestiduras: "De lo que folgara, árbol claro en el límite" ("Imágenes de Guernica en un cuarto de hotel" [96-97]). Y en el poema "La virgen cuando resbala": "y la máscara me quito, la sotana y los calzones al confesarte/ beata de mi devoción dejo a ti mi rendimiento incondicional:/ ni por el ágil y aceitado talle que monto como furtivo jinete/ a lomos de satiresa, ni por tan

\footnotetext{
${ }^{6}$ René de Costa se refiere así sobre Temblor de cielo (1931) de Vicente Huidobro: “Aquí, sin embargo, la expresión es más directa, menos velada: la mujer como atracción, imán/aimant que arrastra al hombre con tanta fuerza como la muerte." (Altazor. Temblor de cielo 42). La mujer como atracción (imán) se presenta también en la poesía de Eduardo Espina. En este sentido también se podría establecer un acercamiento con la atracción hacia el cuerpo en los poemas de César Moro y Braulio Arenas.

${ }^{7}$ En el caso de Eduardo Espina el "bolo alimenticio" representa un símbolo fálico, a diferencia de la poesía de Carlos Germán Belli que aún contando con intensidades eróticas, éstas están regidas por otras constantes. A propósito John Garganigo ha escrito que el "acto sexual" aparece en Belli "como una vía que conduce a la autointrospección y al autoconocimiento ..." En este sentido el hablante belliano busca la plenitud y la satisfacción. Ver Carlos Germán Belli. Antología crítica. Selección y notas de John Garganigo (Hanover: Ediciones del Norte, 1988) 165. El hablante de Espina encuentra la plenitud a través de las relaciones eróticas, siendo el acto sexual una vía para la satisfacción del cuerpo y del lenguaje.
} 
fermosa figura atada al tropo de negros encajes ..." (162). Estos versos poseen un sentido casi profano: la sotana, la beata, la virgen, y la fuerza de un jinete teniendo como fondo el color negro representan la fuerza erótica consumada del amor.

Lo mismo que Trilce de César Vallejo, Altazor de Vicente Huidobro, Lamasmédula de Oliverio Girondo o Dador de Lezama Lima, La caza nupcial de Eduardo Espina es un libro seminal en la poesía hispanoamericana del siglo veinte. Al establecer nuevos espacios de significación, inaugura una dicción poétic adistinta y autorreferente. Tanto desde el punto de vista sintáctico, paradigmático o grafémico, el libro es una verdadera actualización de la poesía. La tipografía de los textos crea una nueva forma en la escritura poemática, ésta a su vez desarrolla una sintaxis que mantiene su coherencia debido al ritmo y al conteo silábico. Por su otredad esta poesía se puede relacionar con la lírica del Barroco, pero más allá de las escuelas, crea un modelo que tiene como base el acoplamiento consecutivo de imágenes que provienen del lenguaje culto del Siglo de Oro español y del lenguaje popular contemporáneo. La renovación que propone este libro tiene una resolución ideológica y literaria bien definida: el hablante de Espina se retira del territorio del facilismo para crear una poesía cuya madurez proviene del placer dotado de intelecto, y nos hace recordar que sólo lo dificil es estimulante, como quería Lezama Lima. Con La caza nupcial Espina arriesga en todo sentido, y se ubica entre los poetas más innovadores de la poesía hispanoamericana de este fin de siglo.

\section{OBRAS CITADAS}

Belli, Carlos Germán. Antología crítica. Selección y notas de John Garganigo. Hanover: Ediciones del Norte, 1988.

Espina, Eduardo. Valores personales. Buenos Aires: Ediciones La Máquina de Escribir, 1983.

La caza nupcial. Buenos Aires: Ediciones Último Reino, 1993.

Huidobro, Vicente. Altazor. Temblor de cielo, ed. René de Costa. Madrid: Cátedra, 1988.

Kirkpatrick, Gwen. The Dissonant Legacy of Modernismo. Berkeley: University of California Press, 1990.

Lastra, Pedro. "Notas sobre la poesía hispanoamericana actual". Inti: Catorce poetas hispanoamericanos de hoy (Número especial). Pedro Lastra y Luis Eyzaguirre, eds. Inti 18-19 (1983-1984).

Legault, Christine. "Poesía hispanoamericana postvanguardistay manierismo: dimensiones formales de una intertextualidad cultural": Tesis doctoral, University of Iowa, 1987.

Milán Eduardo. "Valores personales." Vuelta 138 (1988) 54.

Santí, Enrico Mario. Escritura y tradición. Barcelona: Editorial Laia, 1987.

Sarduy, Severo. Ensayos generales sobre el Barroco. México: Fondo de Cultura Económica, 1987.

Smith, Paul Julian. The Body Hispanic. Gender and Sexuality in Spanish and Spanish American Literature. New York: Oxford University Press, 1989.

Sucre, Guillermo. La máscara, la transparencia. México: Fondo de Cultura Económica, 1985.

Zapata, Miguel-Ángel. Coloquios del oficio mayor. Inti 26-27 (1987-1988). 